\title{
KEMAMPUAN APRESIASI SASTRA SISWA SMA DI KOTA MEDAN
}

\section{LITERATURE APPRECIATION ABILITY OF HIGH SCHOOL STUDENTS IN MEDAN}

\author{
Rehan Halilah Lubis dan Nurelide \\ Balai Bahasa Sumatera Utara \\ Jalan Kolam (Ujuang) Nomor 7 Medan Estate \\ Rehanhalilah12@gmail.com \\ Nurelide71@yahoo.com
}

Naskah diterima tanggal 22 Juli 2019

Naskah direvisi terakhir tanggal 6 Desember 2019

\begin{abstract}
Abtract
Literary learning systems have not used the ability to appreciate literature. Many teachers who teach literature only based on knowledge about teaching and learning activities feel monotonous and boring.In the 2013 curriculum, the literature learning system is always for students to appreciate literature based on literary text. Students ability to appreciate literary works is hoped to increase due to the application of the 2013 curriculum. However, there are so many students who have not been able to do it. The purpose of this research to find out the ability to appreciate student literature.theobjectives of the research method was carried out using quantitative descriptive method with a sample of 55 students from 3 schools in Medan City. The data collection technique is done by tests. Students are asked to answer questions about short stories entitled 'JuruMasak. The test refers to the students' ability to understand literature based on the elements of literature and understand the use of language through literary work. The results of this study indicate that the average value of students' literary appreciation amounts to 88,465 and can be said to be good. While the value of the ability to understand language through literary works the value of the average ability to understand students' language amounts to 66,465. The value of 66,465 shows the results of the ability to understand student language quite well and still need to be improved
\end{abstract}

Key Words: ability, appreciation, literature

\begin{abstract}
Abstrak
Sistem pembelajaran sastra belum mengarahkan pada kemampuan mengapresiasi sastra. Banyak guru yang mengajar sastra hanya berdasarkan pengetahuan tentang sastra sehingga kegiatan belajar mengajar terasa monoton dan membosankan. Pada kurikulum 2013, sistem pembelajaran sastra senantiasa mengarahkan siswa untuk mampu mengapresiasi sastra berdasarkan teks sastra. Berjalan hampir 5 tahun penerapan kurikulum 2013 kemampuan apresiasi siswa terhadap karya sastra sudah tentu meningkat. Namun pada kenyataannya banyak siswa yang belum mampu mengapresiasi sastra. Berdasarkan hal itu tujuan penelitian ini ingin mengetahui kemampuan mengapresiasi sastra siswa. Untuk menghasilkan tujuan tersebut, metode penelitian yang dilakukan dengan metode kuantitatif deskriftif dengan sampel 55 siswa dari 3 sekolah di Kota Medan. Teknik pengambilan data dilakukan dengan tes. Siswa diminta menjawab pertanyaan tentang cerpen berjudul'Juru Masak'. Tes sersebut mengacu pada kemampuan memahami sastra berdasarkan unsur-unsur karya sastra dan memahami penggunaan bahasa melalui karya sastra. Hasil penelitian ini menunjukkan bahwa nilai rata-rata apresiasi sastra siswa berjumlah 88,465 dan dapat dikatakan sudah baik. Sedangkan nilai kemampuan memahami bahasa melalui karya sastra nilai rata-rata kemampuan memahami bahasa siswa berjumlah 66,465. Nilai 66,465 menunjukkan hasil kemampuan memahami bahasa siswa cukup baik dan masih perlu ditingkatkan.
\end{abstract}

Kata kunci: kemampuan, apresiasi, sastra 


\section{PENDAHULUAN}

Pembelajaran sastra merupakan bagian dari mata pelajaran bahasa Indonesia yang sudah dilakukan pada tingkat sekolah dasar sampai tingkat SMA. Pembelajaran sastra mengarahkan pada kemampuan siswa dalam mengapresiasi karya sastra. Melalui pembelajaran sastra diharapkan siswa mampu memaknai karya sastra sehingga pembelajaran sastra benar-benar bermanfaat bagi siswa.

Gaung kegagalan pembelajaran apresiasi sastra di sekolah sudah lama terdengar. Banyak pengamat menilai pembelajaran apresiasi sastra selama ini berlangsung monoton, tidak menarik, bahkan membosankan. Siswa tidak diajak untuk menjelajah dan menggauli keagungan nilai yang terkandung dalam teks sastra, tetapi sekadar diperkenalkan dengan pengetahuanpengetahuan tentang sastra yang bercorak teoretis dan hafalan. Mereka tidak diajak untuk mengapresiasi (baca: memahami dan menikmati) teks-teks sastra yang sesungguhnya, tetapi sekadar menghafalkan nama-nama sastrawan berikut hasil karyanya. Dengan kata lain, apa yang disampaikan guru dalam pembelajaran sastra barulah kulitnya saja, sehingga peserta didik gagal menikmati "lezat"-nya isi dan aroma kandungan nilai dalam karya sastra. Kondisi pembelajaran yang semacam itu tidak saja memprihatinkan, tetapi juga telah "membusukkan" prosespencerdasan emosional dan spiritual siswa.

Pembelajaran apresiasi sastra belum disampaikan atau diajarkan secara maksimal oleh guru bahasa dan sastra Indonesia membuat daya apresiasi dan minat siswa terhadap pembelajaran apresiasi sastra tidak berkembang. Padahal mengapresiasi karya sastra merupakan kegiatan yang perlu dilakukan siswa untuk mengapresiasikan pikiran dan perasaan siswa. Pembelajaran apresiasi sastra seharusnya menjadi pembelajaran yang menyenangkan dan mengajak siswa mengapresiasikan pikiran dan perasaan melalui karya sastra tersebut.

Di samping itu Hamzah (2003) mengemukakan bahwa guru kurang berminat dalam kegiatan apresiasi sastra sehingga pembelajaran apresiasi sastra cenderung monoton dan tidak bervariasi. Guru tidak termotivasi untuk berkreasi dalam pembelajaran tersebut. Pembelajaran apresiasi sastra terkesan membosankan dan tidak menarik siswa. Didukung oleh minat baca siswa terhadap karya sastra rendah, sarana dan prasarana tidak memadai, misal perpustakaan yang tidak mengoleksi bukubuku sastra dan tidak ada media pembelajaran apresiasi sastra yang menarik (hlm. 18-19).

Hal itu sesuai dengan yang dikemukakan oleh Endraswara (2002) dalam sekian tulisan mengenai pengajaran sastra di Indonesia kerap mempersoalkan kebobrokan dan kelemahan atau dalam istilah yang keren disebut "terkena infeksi", "terjangkit virus kronis", dan "suram". Kondisi-kondisi itu menjadi sebab pengajaran sastra bisa membuat "perut mual" dan "influenza berat".

Sejalan dengan hal itu, Iswandari seorang siswa dalam esainya, pemenang I peneulisan esai di Balai Bahasa Sumatera Utara (2004) menyatakan banyak siswa yang mengeluh bahwa pelajaran sastra di sekolah sangat membosankan. Sebagian besar bukubuku di perpustakaan di sekolah adalah buku-buku yang lama menurut mereka kuno dan tidak sesuai lagi dengan zaman (hlm. 1).

Di sekolah, pembelajaran sastra dimaksudkan untuk meningkatkan kemampuan siswa mengapresiasi karya sastra. Kegiatan mengapresiasi sastra berkaitan dengan latihan mempertajam perasaan, penalaran, daya khayal, serta kepekaan terhadap masyarakat, budaya dan lingkungan hidup. Pengembangan kemampuan bersastra di sekolah dilakukan dalam berbagai jenis dan bentuk melalui kegiatan mendengarkan, berbicara, membaca, dan menulis. Adapun pemilihan bahan ajar tersebut dapat dicari pada sumbersumber yang relevan (Depdiknas, 2003 ).

Inovasi kurikulum terus dilakukan untuk meningkatkan kemampuan apresiasi sastra. Strategi pembelajaran sastra sebaiknya disesuaikan dengan tujuan yang ingin dicapai. Langkah-langkah kegiatan belajar 
mengajar harus mengarah pada pencapaian tujuan pembelajaran sastra. Dengan demikian, perumusan tujuan pembelajaran sastra sejalan dengan rumusan tujuan kurikulum berbasis teks yang sebelumnya berbasis kompetensi.

Pada kurikulum KTSP, sistem pembelajaran mengarahkan pada kemampuan apresiasi sastra yang menitik beratkan pada pendekatan komunikatif dan struktur sastra. Berbeda halnya dengan kurikulum 2013, pembelajaran sastra menitik beratkan pada kemampun apresiasi sastra berbasis teks.

Hal tersebut sesuai dengan Kurikulum 2013 (2013) bahasa Indonesia, Teks dapat diperinci ke dalam berbagai jenis, seperti deskripsi, penceritaan (recount), prosedur, laporan, eksplanasi, eksposisi, diskusi, surat, iklan, catatan harian, negosiasi, pantun, dongeng, anekdot, dan fiksi sejarah. Semua jenis teks itu dapat dikelompokkan ke dalam teks cerita, teks faktual, dan teks tanggapan. Dua kelompok yang disebut terakhir itu merupakan teks nonsastra yang masing-masing dapat dibagi lebih lanjut menjadi teks laporan dan teks prosedural serta teks transaksional dan teks ekspositori. Sementara itu, teks cerita merupakan jenis teks sastra yang dapat diperinci menjadi teks cerita naratif dan teks cerita nonnaratif (hlm. VI).

Berkaitan dengan Kurikulum 2013, Sayuti A mengemukakan dalam http://www.jurnal. ump.ac.id/index.php/METAFORA/article/vie w/274 Kurikulum2013, perspektif teoretis yang mempertimbangkan "membaca" sastra sebagai proses "transmission," yang implikasinya dalam praktik pembelajaran lebih menekankan delivery system, yang mengakibatkan siswa pasif dan pembelajaran juga menjadi begitu kognitif, harus dihindari. Sebagai alternatifnya, pandangan yang mempertimbangkan sastra bukan sebagai sebuah objek, melainkan sebagai sebuah pengalaman, dan pembaca bukanlah konsumen, melainkan peraga aktif yang membawa teks ke dalam kehidupan pikirannya, dapat dimanfaatkan. Pandangan ini mengubah fokus perhatian terhadap sastra: dari teks ke pembaca. Tatkala berhadapan dengan teks, aktivitas pembaca hampir dipastikan selalu tidak bebas hambatan, baik hambatan tekstual maupun kultural. Pembacaan dipandu oleh teks dan dipengaruhi oleh sejarah pembaca, baik yang personal, literer, maupun kultural; di samping juga oleh sistem kepercayaan dan konvensikonvensi membaca yang telah diinternalisasikan, yakni "repertoir" dan atau "bingkai ekstratekstual."

Kurikulum 2013 sudah berjalan selama empat tahun. Namun dalam pengamatan dan wawancara dengan beberapa guru, masih banyak guru yang bingung dalam mengajarkan sastra berbasis teks. Tidak sedikit juga guru yang mengajar sastra berdasarkan unsur-unsur karya sastra dan pengetahuan sastra. Akibatnya, sistem pembelajaran sastra tidak sampai pada penghayatan dan penggalian nilai-nilai dan apresiasi karya sastra.

Tidak bisa dipungkiri bahwa kekurangan pada sistem pembelajaran sastra salah satunya pemilihan metode yang kurang tepat. Menurut Jabrohim (1994) metode yang digunakan dalam pembelajaran apresiasi sastra antara lain: (a) membacakan, kegiatan membacakan karya sastra dapat dilakukan dengan mengambil bagian-bagian yang menarik dari karya sastra yang akan dibicarakan. Tentu saja karya sastra dibacakan dengan gaya baca yang meyakinkan sehingga dapat memancing siswa untuk membaca sendiri karya sastra tersebut; (b) meragakan, dilakukan untuk memantapkan penghayatan siswa. Dengan cara mendramatisasikan bagian-bagian tertentu yang menarik atau penting dan membuat diagram mengenai kejadian tertentu atau merekonstruksi suatu peristiwa yang terjadi dalam karya sastra tersebut; (c) mengajukan pertanyaan, tanya jawab dapat dilakukan oleh guru dengan siswa atau antar siswa bertujuan untuk menarik minat siswa, memberi penguatan, mengetahui sejauh mana pemahaman siswa, membimbing suatu penemuan, memancing diskusi, dan sebagainya; (d) mendiskusikan, manfaat diskusi dalam pembelajaran apresiasi sastra sangat besar. Di samping menumbuhkan 
apresiasi juga menumbuhkan gairah membaca karya-karya sastra, buku-buku mengenai sastra, dan sebagainya. Bahanbahan yang didiskusikan dapat berupa unsur intrinsik, ekstrinsik, kesan umum terhadap karya sastra tersebut, dan sebagainya; dan (e) memberikan tugas, pembelajaran apresiasi sastra dilakukan secara bertahap dan berkelanjutan (hlm. 77).

Menurut Sayuti (2002) apresiasi merupakan hasil usaha membaca dalam mencari dan menemukan nilai hakiki puisi lewat pemahaman dan penafsiran sistematik yang dapat dinyatakan dalam bentuk tertulis. Melalui kegiatan apresiasi itu, diharapkan timbul kegairahan dalam diri pembaca untuk lebih memasuki dunia puisi, berbagai dunia yang juga menyediakan alternatif pilihan untuk menghadapi permasalahan kehidupan yang sebenarnya (hlm. 365).

Menurut Rusyana (2003) ada 3 komponen dalam pembelajaran sastra, yaitu:

1) kemampuan mengapresiasi sastra, meliputi kegiatan mendengarkan, menonton, dan membaca hasil nsastra;

2) kemampuan berekpresi sastra, meliputi: kegiatan melisankan hasil sastra dan menulis karya sastra;

3) kemampuan menelaah hasil sastra, meliputi kegiatan menilai, meresensi, dan menganalisis hasil sastra (hlm. 3).

Pengantian kurikulum dan sistem pembelajaran sastra menarik perhatian untuk meneliti kemampuan apresiasi siswa terhadap karya sastra. Berdasarkan latar belakang yang dipaparkan sebelumnya, rumusan masalah dalam penelitian ini kemampuanapresiasisastra peserta didik tingkat SMA melalui kegiatan apresiasi sastra.

Pembelajaran apresiasi sastra merupakan perwujudan pembinaan apresiasi sastra untuk mengembangkan rasa etis-estetis para siswa dan menumbuhkan daya kritis serta selektif terhadap karya sastra. Atau dengan kata lain, pembelajaran apresiasi sastra merupakan penghargaan terhadap keberadaan cipta sastra. Belajar sastra juga belajar menghargai manusia dan nilai-nilai kemanusiaannya (Moody dalam Andayani, 2004:3-4).

bahwa $\begin{array}{cr}\text { Alwasilah (2006) } & \text { mengemukakan } \\ \text { pentingnya } & \text { memasukkan }\end{array}$
pembelajaran sastra di sekolah karena ada berbagai alasan, yaitu karya sastra menjembatani hubungan realita dan fiksi, hal ini mendukung kecenderungan manusia yang menyukai realita dan fiksi. Melalui karya sastra, pembaca belajar dari pengalaman orang lain dalam menghadapi masalah dalam kehidupan

Apresiasi berarti mengenal, memahami, menikmati dan menilai. Menurut Waluyo (2002:44) apresiasi biasanya dikaitkan dengan seni. Apresiasipuisi berkaitan dengan kegiatan yang ada sangkut pautnya dengan puisi, yaitumendengar atau membaca puisi dengan penghayatan yang sungguh-sungguh, apresiasi puisi, mendeklamasikan, dan apresiasi resensi puisi. Dalam penerapannya apresiasi memerlukan aktivitas, kreativitas, dan motivasi dalammenunjukkan kemampuan atau potensi seseorang karena apresiasi merupakansebuah proses. Hal tersebut senada dengan pendapat Zaidan (2001) yang menyatakan bahwa apresiasi sastra itu berlangsung dalam suatu proses yangmencakup pemahaman, penikmatan, dan penghayatan. Apresiasi berlangsung melalui proses mengenal, memahami, menghayati, dan menilai dari suatu hal atau karya yang ada dalam suatu kehidupan (hlm. 21).

Menurut Sayuti (2002) apresiasi merupakan hasil usaha membaca dalam mencari dan menemukan nilai hakiki puisi lewat pemahaman dan penafsiran sistematik yang dapat dinyatakan dalam bentuk tertulis. Melalui kegiatan apresiasi itu, diharapkan timbul kegairahan dalam diri pembaca untuk lebih memasuki dunia puisi, berbagai dunia yang juga menyediakan alternatif pilihan untuk menghadapi permasalahan kehidupan yang sebenarnya (hlm. 365).

Dalam pembelajaran sastra, karya sastra disajikan dalam bentuk puisi, prosa dan drama. Semua bentuk karya sastra ini dipelajari dan diarahkan pada kemampuan apresiasi sastra. Dengan pembelajaran sastra, 
siswa diharapkan mampu menghargai, memaknai dan menemukan nilai-nilai budaya yang terkandung dalam karya sastra.

Penelitian tentang kemampuan apresiasi sastra siswa sudah dilakukan oleh susi Fitria dengan judul Kemampuan Siswa Menentukan Tokoh, Karakter Tokoh, dan Latar Cerpen pada Buku Teks Bahasa Indonesia Siswa Kelas VII SMP Negeri 11 Kota Jambi,. Hasil penelitiannya menunjukkan bahwa kemampuan siswa kelas VII SMP Negeri 11 Kota Jambi Tahun 2013/2014 dalam mengidentifikasi tokoh, karakter tokoh, dan latar cukup dengan jumlah nilai rata-rata 62 .

Penelitian tentang apresiasi sastra tingkat SMA juga dilakukan oleh Riski Puspita Sari, Martono, Agus Wartiningsihyang berjudul Kemampuan Mengidentifikasi Unsur Instrinsik Cerpen Siswa Kelas Xi SMA Negeri 1 Semparuk.Berdasarkan hasil analisis data, kemampuan siswa mengidentifikasi alur cerpen berkategori cukup dengan nilai persentase $74.24 \%$, kemampuan siswa mengidentifikasi penokohan cerpen berkategori baik dengan nilai persentase 83.32\%, kemampuan siswa mengidentifikasi latar cerpen berkategori cukup dengan nilai persentase $74.02 \%$, kemampuan siswa mengidentifikasi amanat cerpen berkategori baik dengan nilai persentase $84.84 \%$, kemampuan siswa mengidentifikasi unsur instrinsik cerpen semua aspek berkategori cukup, dengan nilai persentase $77.41 \%$.

Riski Puspita Sari, Martono, Agus

Wartiningsih.http://jurnal.untan.ac.id/index.p hp/jpdpb/article/download/10690/10225

diakses tangga 19 Desember 2018 jam 12:30.

\section{METODE PENELITIAN}

Untuk menjawab permasalahan tersebut, metode kuantitatif digunakan dengan instrumen penelitian berbentuk tes pemahaman karya sastra. Adapun variabel yang dianalisis yaitu nilai apresiasi sastra siswa yang dibagi dalam empat kategori pertanyaan yaitu 1) kemampuan memaknai isi cerpen, 2) kemampuan memahami, tema, tokoh, penokohan, latar, konflik, alur, 3) kemampuan memahami pilihan kata, 4) pemahaman isi cerita melalui kalimat.populasi penelitian ini adalah peserta didik tingkat SMA yang ada di Kota Medan Kecamatan Johor, Medan Tuntungandan Medan Polonia.Pemilihan sampel dalam penelitian ini dilakukan dengan teknik sampel acak (simple random sampling). Teknik ini dipilih karena jumlah peserta didik tingkat SMA diKota Medan cukup banyak. Oleh sebab itu, dalam penelitian ini hanya dipilih sebanyak 55 responden, yaitu dari SMA Al Azhar, SMAN 17 Medan dan SMA Negeri 2 Medan.

Sebelum dilakukan analisis data, deskripsi variabel hasil penelitian perlu dilakukan. Deskripsi kuantitatif dilakukan dengan menggunakan program SPSS 17 for windows. Adapun variabel yang dianalisis yaitu nilai apresiasi sastra siswa yang dibagi dalam empat kategori pertanyaan yaitu 1) kemampuan memaknai isi cerpen, 2) kemampuan memahami, tema, tokoh, penokohan, latar, konflik, alur, 3) kemampuan memahami pilihan kata, 4) pemahaman isi cerita melalui kalimat. Hasil kemampuan apresiasi sastra ini akan dideskripsikan berdasarkan kategori dan selanjutnya dijumlahkan menjadi nilai apresiasi sastra. Pada bab ini juga akan dideskripsikan nilai apresiasi sastra siswa ditinjau dari asal sekolah.

\section{PEMBAHASAN}

\section{Kemampuan Memaknai Isi Cerpen}

Untuk menilai kemampuan memaknai isi cerpen, pertanyaan yang diajukan pada peserta didik berjumlah 5 pertanyaan. Pertanyaan yang diajukan berupa permasalahan yang dihadapi tokoh utama dan cara tokoh utama mengatasi masalah dalam cerpen "Juru Masak". Adapun hasil jawaban siswa dapat dilihat dalam tabel berikut ini.

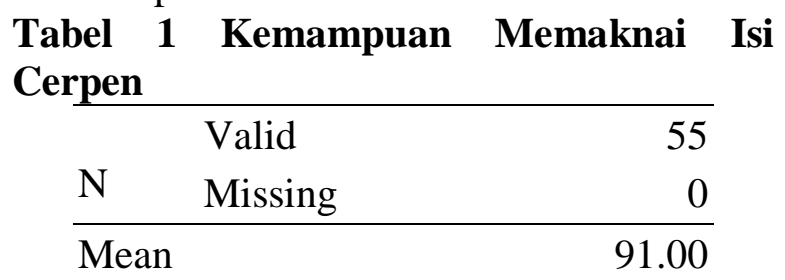




\begin{tabular}{lr}
\hline Median & 90.00 \\
Std. Deviation & 7.157 \\
Minimum & 75 \\
Maximum & 100 \\
\hline
\end{tabular}

Dari tabel di atas, nilai rata-rata kemampuan memaknai isi cerpen siswa berjumlah 91,00. Nilai 91,00 menunjukkan bahwa kemampuan memaknai isi cerpen siswa sangat baik dengan nilai tertinggi 100 dan terendah 75. Standar deviasi berjumlah 7.157 menunjukkan hasil jawaban siswa berpariasi dilihat jarak antara nilai tertinggi dan terendah 25 poin.

Kemampuan Memahami, Tema, Tokoh, Penokohan, Latar, Konflik, Alur

Untuk menilai kemampuan memahami, tema, tokoh, penokohan, latar, konflik, alur, pertanyaan yang diajukan pada peserta didik berjumlah 9 pertanyaan. Pertanyaan yang diajukan berupa kemampuan memahami, tema, tokoh, penokohan, latar, konflik, alur dalam cerpen "Juru Masak" . Adapun hasil jawaban siswa dapat dilihat dalam tabel berikut ini.

Tabel 2 Kemampuan Kemampuan Memahami, Tema, Tokoh, Penokohan, Latar, Konflik, Alur

\begin{tabular}{|c|c|c|}
\hline \multirow[t]{2}{*}{$\mathrm{N}$} & Valid & 55 \\
\hline & Missing & 0 \\
\hline \multicolumn{2}{|c|}{ Mean } & 85.93 \\
\hline \multicolumn{2}{|c|}{ Median } & 85.00 \\
\hline \multicolumn{2}{|c|}{ Std. Deviation } & 7.236 \\
\hline \multicolumn{2}{|c|}{ Minimum } & 45 \\
\hline \multicolumn{2}{|c|}{ Maximum } & 99 \\
\hline
\end{tabular}

Dari tabel di atas, nilai rata-rata kemampuan memahami, tema, tokoh, penokohan, latar, konflik, alur siswa berjumlah 85,93 . Nilai 85,93 menunjukkan bahwa kemampuan memahami, tema, tokoh, penokohan, latar, konflik, alur siswa sangat baik dengan nilai tertinggi 99 dan terendah 45. Standar deviasi berjumlah 7.236 menunjukkan hasil jawaban siswa berpariasi dilihat jarak antara nilai tertinggi dan terendah berjumlah 44 poin.

\section{Kemampuan Memahami Pilihan Kata dalam Cerpen}

Untuk menilai kemampuan memahami pilihan kata, pertanyaan yang diajukan pada peserta didik berjumlah 9 pertanyaan. Pertanyaan yang diajukan berupa pemahaman kosa kata yang digunakan dalam cerpen "Juru Masak" dan penggunaan kalimat.. Adapun hasil jawaban siswa dapat dilihat dalam tabel berikut ini.

Tabel 3 Kemampuan Memahami Kosa Kata

\begin{tabular}{|c|c|c|}
\hline \multirow[t]{2}{*}{$\mathrm{N}$} & Valid & 55 \\
\hline & Missing & 0 \\
\hline \multicolumn{2}{|c|}{ Mean } & 48.47 \\
\hline \multicolumn{2}{|c|}{ Median } & 54.00 \\
\hline \multicolumn{2}{|c|}{ Std. Deviation } & 13.270 \\
\hline \multicolumn{2}{|c|}{ Minimum } & 24 \\
\hline \multicolumn{2}{|c|}{ Maximum } & 60 \\
\hline
\end{tabular}

Dari tabel di atas, nilai rata-rata kemampuan memahami kosa kata siswa berjumlah 48.47 . Nilai 48.47 menunjukkan bahwa kemampuan memahami bahasasiswa tidak baik dengan nilai tertinggi 60 dan terendah 24. Standar deviasi berjumlah 13.270 menunjukkan hasil jawaban siswa sangat berpariasi dilihat jarak antara nilai tertinggi dan terendah 36 poin. Variasi nilai jawaban siswa dapat dilihat dalam lampiran.

\section{Kemampuan Memahami Kalimatdalam Cerpen}

Untuk menilai kemampuan memahami kalimat, pertanyaan yang diajukan pada peserta didik berjumlah 10 pertanyaan. Pertanyaan yang diajukan berupa pemahaman tokoh dan peristiwa yang terjadi dalam cerpen "Juru Masak".Pemahaman kalimat dalam cerpen "Juru Masak" menggunakan pertanyaan dengan jawaban benar dan salah .Adapun hasil jawaban siswa dapat dilihat dalam tabel berikut ini. 
Tabel 4 Kemampuan Memahami Kalimat

\begin{tabular}{|l|r|}
\hline N $\quad$ Valid & 55 \\
\multicolumn{1}{|c|}{ Missing } & 0 \\
Mean & 84.45 \\
Median & 82.00 \\
Std. Deviation & 13.355 \\
Minimum & 55 \\
Maximum & 100 \\
\hline
\end{tabular}

Dari tabel di atas, nilai rata-rata kemampuan memahami kalimat siswa berjumlah 84.45 . Nilai 84.45 menunjukkan bahwa kemampuan memahami bahasa siswa baik dengan nilai tertinggi 100 dan terendah 55. Standar deviasi berjumlah 13.335 menunjukkan hasil jawaban siswa sangat berpariasi dilihat jarak antara nilai tertinggi dan terendah 45 poin. Variasi nilai jawaban siswa dapat dilihat dalam lampiran.

\section{Kemampuan Mengapresiasi Sastra}

Untuk menilai kemampuan mengapresiasi sastra sebagai variabel $X$, pertanyaan yang diajukan berupa kemampuan memaknai isi cerpen, dan kemampuan memahami, tema, tokoh, penokohan, latar, konflik, alur. Adapun hasil jawaban siswa dapat dilihat dalam tabel berikut ini.

Tabel 5 Kemampuan Mengapresiasi Sastra

\begin{tabular}{|l|r|}
\hline N $\quad$ Valid & 55 \\
& Missing \\
Mean & 0 \\
Median & 176.93 \\
Std. Deviation & 177.00 \\
Minimum & 9.899 \\
Maximum & 140 \\
\hline
\end{tabular}

Dari tabel di atas, nilai rata-rata kemampuan apresiasi siswa berjumlah 176.93. Nilai $176 . .93$ menunjukkan bahwa kemampuan mengapresiasi sastra siswa baik dengan nilai tertinggi 195 dan terendah 140 . Standar deviasi berjumlah 9.899 menunjukkan hasil jawaban siswa sangat berpariasi dilihat jarak antara nilai tertinggi dan terendah 55 poin. Variasi nilai jawaban siswa dapat dilihat dalam lampiran.

\section{Kemampuan Memahami Bahasa}

Untuk menilai kemampuan memahami bahasa sebagai variabel $\mathrm{Y}$, pertanyaan yang diajukan berupa kemampuan memahami kosa kata dan kalimat. Adapun hasil jawaban siswa dapat dilihat dalam tabel berikut ini.

\section{Tabel 6 Kemampuan Memahami bahasa}

\begin{tabular}{lr}
\hline N $\quad$ Valid & 55 \\
\multicolumn{1}{r}{ Missing } & 0 \\
\hline Mean & 132.93 \\
Median & 133.00 \\
Std. Deviation & 18.104 \\
Minimum & 79 \\
Maximum & 159 \\
\hline
\end{tabular}

Dari tabel di atas, nilai rata-rata kemampuan memahami bahasa siswa berjumlah 132. 93. Nilai $132 . .93$ menunjukkan bahwa kemampuan memahami bahasa siswa cukup baik dengan nilai tertinggi 159 dan terendah 79. Standar deviasi berjumlah 18.104 menunjukkan hasil jawaban siswa sangat berpariasi dilihat jarak antara nilai tertinggi dan terendah 80 poin.Variasi nilai jawaban siswa dapat dilihat dalam lampiran.

\section{Hasil Kemampuan Apresiasi Siswa Ditinjau dari Asal Sekolah \\ Data kemampuan apresiasi belajar siswa diambil dari tiga sekolah yaitu SMA Swasta Al Azhar Medan, SMA Negeri 17 Medan, dan SMA Negeri Medan.}


Tabel 4.7 Hasil Kemampuan Apresiasi Siswa Ditinjau dari Asal Sekolah

\begin{tabular}{lrrlll}
\hline Asal Sekolah & & Mean & $\begin{array}{l}\text { Std. } \\
\text { Devisasi }\end{array}$ & Minimum & Maksimum \\
\hline $\begin{array}{l}\text { SMA Swasta } \\
\text { Azhar Medan }\end{array}$ & Al- & 180.60 & 13.553 & 140 & 195 \\
$\begin{array}{l}\text { SMA Negeri } \\
\text { Medan }\end{array}$ & 17 & 175.00 & 7.635 & 161 & 187 \\
$\begin{array}{l}\text { SMA Negeri 2 } \\
\text { Medan }\end{array}$ & 175.88 & 8.212 & 158 & 186 \\
\hline
\end{tabular}

Dari tabel di atas, nilai rata-rata kemampuan siswa ditinjau dari asal sekolah SMA Swasta Al Azhar Medan nilai rata-rata 180.60, SMA Negeri 17 berjumlah 175.00, dan SMA Negeri 2 Medan 175,88. Dilihat dari nilai rata-rata SMA nilai apresiasi sastra siswa SMA Al Azhar lebih tinggi dibandingkan dengan SMA Negeri 17 dan SMA Negeri 2 Medan. Nilai apresiasi siswa SMA Negeri 17 hampir sama dengan nilai rata-rata siswa SMA Negeri 2 Medan. Nilai Apresiasi sastra siswa berdasarkan kelompok jawaban dapat dikatakan nilai rata-rata jawaban siswa berjumlah 90, begitu pula dengan SMA Negeri 17 dan SMA Negeri 2 Medan mendapat nilai rata-rata 87,5. Dari hasil nilai yang dicapai siswa menunjukkan bahwa kemampuan apresiasi siswa sudah baik.

Standar deviasi hasil jawaban siswa menunjukkan bahwa nilai SMA Al Azhar lebih bervariasi dibandingkan dengan nilai SMA Negeri 17 dan SMA Negeri 2. Variasi nilai jawaban siswa dapat dilihat dalam lampiran.

Hasil Kemampuan Memahami BahaSa Siswa Ditinjau dari Asal Sekolah

Data Kemampuan memahami bahasa belajar siswa diambil dari tiga sekolah yaitu SMA Swasta Al Azhar Medan, SMA Negeri 17 Medan, dan SMA Negeri Medan.

Tabel 8 Hasil Kemampuan Memahami Bahasa Siswa Ditinjau dari Asal Sekolah

\begin{tabular}{|c|c|c|c|c|}
\hline Asal Sekolah & Mean & $\begin{array}{l}\text { Std. } \\
\text { Devisasi }\end{array}$ & Minimum & Maksimum \\
\hline $\begin{array}{l}\text { SMA Swasta Al- } \\
\text { Azhar Medan }\end{array}$ & 117.80 & 20.065 & 75 & 159 \\
\hline $\begin{array}{l}\text { SMA Negeri } 17 \\
\text { Medan }\end{array}$ & 136.20 & 14.878 & 106 & 157 \\
\hline $\begin{array}{l}\text { SMA Negeri } 2 \\
\text { Medan }\end{array}$ & 140 & 12.986 & 106 & 157 \\
\hline
\end{tabular}

Dari tabel di atas, nilai rata-rata kemampuan memahami bahasasiswa ditinjau dari asal sekolah SMA Swasta Al Azhar Medan nilai rata-rata 117, SMA Negeri 17 berjumlah 136.00, dan SMA Negeri 2 Medan 140. Dilihat dari nilai rata-rata SMA nilai memahami bahasa siswa SMA Al Azhar lebih rendah dibandingkan dengan SMA Negeri 17 dan SMA Negeri 2 Medan. Nilai apresiasi siswa SMA Negeri 17 hampir sama dengan nilai rata-rata siswa SMA Negeri 2 Medan. Nilai memahami bahasasiswa berdasarkan kelompok jawaban dapat dikatakan nilai rata- rata jawaban siswa SMA Swasta Al-Azhar berjumlah 58.9, dengan SMA Negeri 17 memiliki nilai rata-rata 68.1 dan SMA Negeri 2 Medan mendapat nilai rata-rata-rata 70. Dari hasil nilai yang dicapai siswa menunjukkan bahwa kemampuan memahami bahasa siswa SMA Swasta Al-Azhar kurang baik, dan SMA Negeri 17 masih di bawah standar nilai 70, sedangkan nilai SMA Negeri 2 dengan nilai 70. Dari hasil yang dicapai dapatlah dikatakan kemampuan berbahasa siswa masih perlu diperhatikan dan ditingkatkan.Standar deviasi hasil jawaban siswa menunjukkan bahwa nilai SMA Al 
Azhar lebih bervariasi dibandingkan dengan nilai SMA Negeri 17 dan SMA Negeri 2.

Hasil penelitian kemampuan mengapresiasi karya sastra menunjukkan nilai rata-rata kemampuan apresiasi sastra siswa cukup baik. dengan nilai cukup baik ini dapat disebabkan oleh kurang minatnya siswa terhadap pelajaran sastra dan metode yang dilakukan guru dalam mengajar kurang bervariasi. Disamping itu pergantian kurikulum membuat guru bahasa Indonesia bingung menempatkan pembelajaran sastra pada mata pelajaran bahasa Indonesia.

\section{SIMPULAN DAN SARAN}

Nilai rata-rata kemampuan apresiasi sastra siswa berjumlah 176.93. Nilai 176.93 menunjukkan bahwa kemampuan apresiasi sastra siswa baik dengan nilai tertinggi 195 dan terendah 140. Nilai rata-rata 176.93 ini berasal dari dua kelompok pertanyaan untuk menguji kemampuan apresiasi sastra. Berdasarkan hal itu, dapat dikatakan rata-rata nilai apresiasi sastra siswa berjumlah 88,465 dan dapat dikatakan sudah baik. Nilai rata- rata kemampuan siswamemahami bahasa dalam karya sastra berjumlah 132.93. Nilai 132.93 menunjukkan bahwa kemampuan memahami bahasa siswa cukup baik dengan nilai tertinggi 159 dan terendah 79. Untuk menguji kemampuan berbahasa, siswa juga menggunaan pertanyaan yang dikelompokkan menjadi dua. Berdasarkan hal itu, dapat dikatakan nilai rata-rata kemampuan memahami bahasa siswa berjumlah 66,465. Nilai 66,465 menunjukkan hasil kemampuan memahami bahasa siswa cukup baik dan masih perlu ditingkatkan.

Dari hasil penelitian ini diharapkan menjadi masukan bagi pemerintah, guru serta instansi yang terkait, agar memberi pelatihan Bahasa Indonesia bagi guru-guru bahasa Indonesia. Tujuannya agar dapat menyegarkan kembali pengetahuan tentang bahasa dan sastra guru-guru bahasa Indonesia yang ada di Kota Medan. Selain itu guruguru bahasa Indonesia setiap dua tahun sekali wajib mengikuti tes uji kemahiran bahasa Indonesia (UKBI).

Hamzah. (2003). "Problematika Pengajaran Sastra di Sekolah". Majalah Horizon. Kaki Langit, Juli, Edisi 79, hlm. 18-19

Jabrohim (Ed). 1994. Pengajaran Sastra. Yogyakarta: Gadjah Mada University Press

Rusyana, Y. (2003). Membangun Suasana Demokratis dalam Pendidikan Sastra di Sekolah. Makalah Pleno yang disajikan pada Kongres Bahasa Indonesia VIII di Jakarta, 14-17.

Sayuti

http://www.jurnal.ump.ac.id/index.php/ METAFORA/article/view/274 diakses tanggal 11 Desember 2017

Waluyo, Herman J. (2002). Apresiasi Puisi untuk Pelajar dan Mahasiswa. Jakarta: PT Gramedia Pustaka Utama

Sayuti, Suminto A. (2002). Berkenalan dengan Puisi. Yogyakarta: Gama Media 
Susi Fitria http://103.26.102.47/ eskripsi/data/pdf/jurnal_mhs/artikel/A1 B109076.pdf diakses tanggal 11 Desember 2018

Zaidan, Rozak. (2001). Pedoman Penyuluhan Apresiasi Sastra. Jakarta: Depdiknas 